
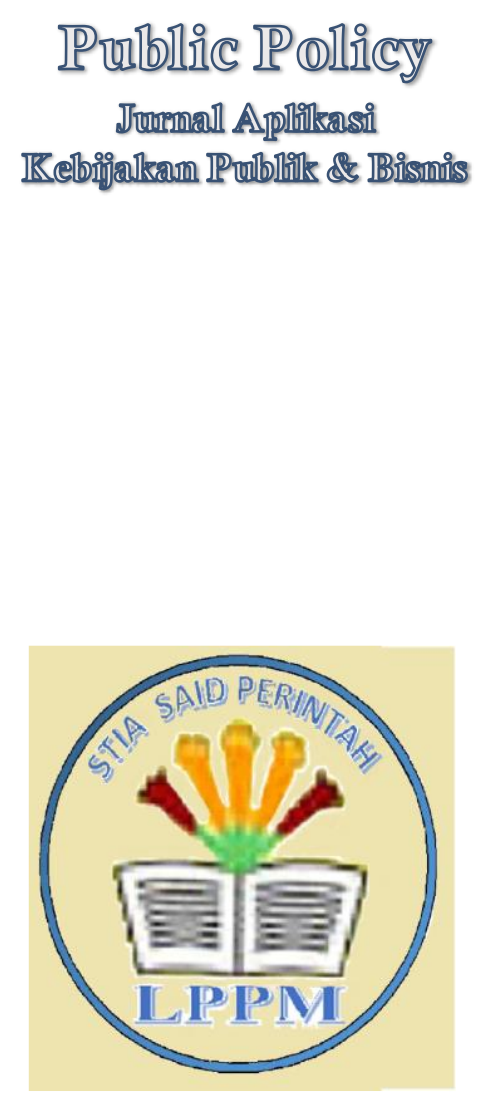

LPPM STIA Said Perintah

Volume 2, No. 1, Maret 2021

https://stia-saidperintah.e-journal.id/ppj

\section{Profesionalisme Kerja Pegawai pada Kantor Dinas Kependudukan dan Pencatatan Sipil Kota Ambon}

\author{
Maryam Salampessy ${ }^{1}$ \\ Matheus Rumaratu ${ }^{2}$ \\ (Penulis Korespondensi)
}

\section{1,2 IImu Administrasi Negara STISIP Kebangsaan Masohi matheusrumaratu@gmail.com}

\begin{abstract}
This study aims to determine the quality of public services at the Ambon City's Population and Civil Registration Service Offices, and the dimensions of employee professionalism which are supporting and inhibiting factors for improving the quality of public services at the Ambon City's Population and Civil Registration Service Offices. The data was collected in this study were analyzed using descriptive qualitative analysis techniques through steps, or components of interactive model data analysis. Data collection techniques used through this research are interviews, observation and documentation. The results of this study indicate, the level of quality of public services by the administering apparatus of the field of population administration and civil registration at the Ambon City's Population and Civil Registration Service is in sufficient condition, this is a contribution of the employee's work professionalism factor.
\end{abstract}

Keywords : Professionalism, Quality of Public Services 


\section{Pendahuluan}

Pelayanan publik yang berkualitas merupakan salah satu faktor penting yang memperoleh perhatian serius untuk terus dilakukan peningkatannya oleh aparat penyelenggara pemerintah daerah saat ini agar menjadi optimal sehingga dapat memenuhi kebutuhan warga masyarakat sesuai haknya berdasarkan ketentuan peraturan perUndang-Undangan yang yang berlaku. Tinggi atau rendahnya kualitas pelayanan publik yang terdapat pada suatu organisasi pemerintahan daerah menjadi ukuran bagi tingkat keberhasilan dan kegagalan organisasi pemerintahan daerah tersebut, termasuk Kantor Dinas Kependudukan dan Pencatatan Sipil pada suatu daerah dalam memberikan pelayanan administrasi kependudukan untuk mencapai sasaran dan tujuan yang diinginkan.

Dinas Kependudukan dan Pencatatan Sipil sebagai SKPD yang membidangi Administrasi Kependudukan dalam pelayanan Pendaftaran Penduduk dan Pencatatan Sipil sesuai dengan sesuai Undang-Undang Nomor 23 Tahun 2006, tentang Administrasi Kependudukan dan Perubahannya Undang-Undang Nomor 24 Tahun 2013 Undang-Undang mempunyai kewenangan melaksanakan pendaftaran penduduk dan pencatatan peristiva penting.

Kemudian dalam Peraturan Pemerintah RI Nomor 37 Tahun 2007 tentang Pelaksanaan Undang-Undang diatas tentang Administrasi Kependudukan, pasal 32 ayat (2), menegaskan bahwa pelayanan pencatatan sipil, meliputi: a) kelahiran, b) kematian, c) lahir mati, d) perkawinan, e) pengakuan anak, f) pengesahan anak, g) pengangkatan anak, h) perubahan nama, j) perubahan status kewarganegaraan, k) pembatalan perkawinan, I) pembatalan perceraian, dan $\mathrm{m}$ ) peristiwa penting lainnya.Selain itu dalam pasal 33, pejabat pencatatan sipil pada UPDT Instansi Pelaksana berwewenang menerbitkan Kutipan Akta Catatan Sipil yang meliputi: a) kelahiran, b) kematian, c) perkawinan, d) perceraian, dan e) pengakuan anak.

Dalam melaksanakan tugas pokok dan fungsi dinas kependudukan dan pencatatan sipil secara terintegrasi menerbitkan dokumen kependudukan dan pencatatan sipil, dalam upaya peningkatan kualitas pelayanan prima kepada masyarakat melalui program three in one/four in one, sekali pengurusan dapat tiga/ empat dokumen KK, KTP, Akta Perkawinan dan Akta Kelahiran Anak (jika sudah memiliki anak sebelum pelaksanaan pencatatan perkawinan). 
Sesuai Peraturan Walikota Ambon Nomor 38 Tahun 2016 Tentang Organisasi dan Tata Kerja Dinas Kota Ambon, bahwa Dinas Kependudukan dan Pencatatan Sipil Kota Ambon mempunyai tugas melaksanakan penyusunan dan pelaksanaan kebijakan dibidang kependudukan dan pencatatan sipil. Melaluinya diharapkan agar para pegawai pada Kantor Dinas Kependudukan dan Pencatatan Sipil Kota Ambon, memiliki profesionalisme kerja yang tinggi sehingga dapat memungkinan mereka dapat menampilkan dan mencapai kinerja yang optimal sebagaimana yang diharapkan.

Sesuai hasil pengamatan yang dilakukan pada Kantor Dinas Kependudukan dan Pencatatan Sipil Kota Ambon, ditemukan beberapa fenomena yang pada dasarnya menunjukan belum optimal kualitas pelayanan pegawai, hal ini ditandai dengan; 1) banyaknya warga masyarakat dalam antrian panjang untuk mengurus dan mendapatkan layanan administrasi kependudukan, 2) kecenderungan pegawai yang begitu lama dalam pemberian layanan kepada warga dengan menunggu nama dipanggil hingga ke meja pelayanan terasa begitu rumit dan mumet. Bahkan tak sedikit yang memilih pulang, 3) masih tertundanya layanan yang harus diperoleh warga masyarakat, dengan alasan terdapat gangguan sistem peralatan, karena padamnya listrik/mesin pencetak berpotensi rusak dan bisa jadi lebih lama lagi perbaikannya. 4) Sementara disisi lain, ditemui pula bahwa tingkat pengetahuan, ketrampilan kerja, kesanggupan kerja, dan pengalaman kerja sebagaian pegawai belum sepenuhnya memadai sebagaimana yang diharapkan, 5) mengenai keramahan beberapa pegawai di Kantor kepada pengguna layanan yang datang. Ketidakramahan tersebut terlihat ketika apabila pelayanan terlalu banyak/berjubel maka pegawai berniat untuk mengatur pun menegur masyarakat masyarakat agak keras meski masih menggunakan bahasa yang wajar.

Pelaksanaan penelitian ini bertujuan untuk menganalisis dan menjelaskan gambaran mengenai kualitas pelayanan publik, serta dimensi-dimensi profesionalisme kerja pegawai yang menjadi faktor-faktor pendukung dan penghambatnya pada Kantor Dinas Kependudukan dan Pencatatan Sipil Kota Ambon.

Berdasarkan latar belakang masalah yang dikemukakan diatas, masalah yang dihadapi dalam penelitian ini dirumuskan adalah; Bagaimana Kualitas Pelayanan Publik Pada Kantor Dinas Kependudukan dan Pencatatan Sipil Kota Ambon dan apa dimensidimensi profesionalisme pegawai yang menjadi faktor-factor pendukung dan penghambat peningkatan kualitas pelayanan publik pada kantor Dinas Kependudukan dan Pencatatan Sipil Kota Ambon. 


\section{Kerangka Teoritis}

Bersumber pada tinjauan pustaka diatas, dapat dikemukakan kerangka teoritis sebagai acuan dalam pelaksanaan penelitian ini. Pelayanan publik yang berkualitas merupakan salah satu faktor penting dan strategis yang saat ini terus memperoleh perhatian serius oleh Pemerintah, Pemerintah Daerah, termasuk pada Dinas Kependudukan dan Pencacatan Sipil Kota Ambon.

Berkaitan dengan hal itu, harus diupayakan peningkatan kualitas pelayanan publik oleh pimpinan dan aparat penyelenggaranya pada suatu organisasi publik atau organisasi pemerintahan daerah guna tercapainya keprofessionalan kinerja pegawai.

\section{Professionalisme Kerja Pegawai}

Menurut Sondang P. Siagian, (2014) profesionalisme kerja pegawai diukur dari segi kecepatannya dalam menjalankan fungsi dan mengacu kepada prosedur yang telah disederhanakan. Menurut pendapat tersebut, konsep profesionalisme dalam diri aparat dilihat dari segi; 1) Kreativitas (Creativity). Kemampuan aparatur untuk menghadapi hambatan dalam memberikan pelayanan kepada publik dengan melakukan inovasi, 2) Inovasi (Innovation) yang perwujudannya berupa hasrat dan tekad untuk mencari, menemukan, dan menggunakan cara baru, metode kerja baru, dalam pelaksanaan tugasnya. Hambatan yang paling mendasar dari perilaku inovatif adalah rasa cepat puas terhadap hasil pekerjaan yang telah dicapai, serta responsivitas (responsible) yang merupakan kemampuan aparatur dalam sesuatu yang baru. Birokrasi harus merespon secara cepat agar tidak tertinggal dalam menjalankan tugas dan fungsinya. Disisi lain Mukarom, Zainal \& Laksana, (2016) menyebutkan ukuran-ukuran untuk melihat profesionalisme kerja pegawai pada suatu organisasi, meliputi; 1) komitmen dan konsistensi, 2) wewenang dan tanggung jawab, 3) integritas dan profesional, 4) ketepatan/keakurasian dan kecepatan, 5) disiplin dan keteraturan kerja, serta 6) penggunaan iptek.

Berdasarkan pendapat diatas, maka profesionalisme kerja pegawai dalam penelitian ini dipahami sebagai kemampuan yang dimiliki (competency)yang dimiliki setiap pegawai sesuai kebutuhan pekerjaan yang diembannya pada suatu organisasi, berupa; a) pengetahuan (knowledge), b) keterampilan (skill), c) kesanggupan melakukan (ability), dalam melaksanakan tugas atau pekerjaannya yang ditunjang dengan, d) pengalaman kerja (experience) yang dimiliki, e) disiplin kerja (discipline), f) kreativitas kerja (creativity), dan g) inovatif kerja pegawai (innovative). 


\section{Kualitas Pelayanan Publik}

Ditegaskan oleh Supriyono, (2001) bahwa;

"Aparatur pemerintah dituntut untuk meningkatkan kinerjanya dalam memberikan pelayanan publik yang berkualitas. Dimulai dari daya tanggap terhadap tuntutan publik, menerjemahkan dalam bentuk perencanaan, pelaksanaan hingga evaluasi yang memerlukan penerapan prinsip "3 Es" (Economy), Effectiveness, Effisiensi) dan "3 $R$ 'S" (Responsiveness, Representativeness, Responsibility)".

Pelayanan publik yang berkualitas mempunyai sejumlah aspek atau dimensi, yang dapat djjadikan ukuran guna melihat intensitasnya pada suatu organisasi. Kualitas pelayanan publik menurut Fitzimmons (Sedarmayanti., 2012), dapat dilihat pada lima dimensi, berikut: a) Reliability, kemampuan memberikan secara tepat dan benar, jenis pelayanan yang telah dijanjikan kepada masyarakat, b) Responsiveness, kesadaran atau keinginan untuk membantu dan memberikan pelayanan cepat kepada masyarakat, c) Assurance, pengetahuan atau wawasan, kesopanan, kesantunan, kepercayaan diri dari pemerintah, serta respek terhadap masyarakat, d) Empathy, kemauan pemerintah untuk melakukan pendekatan, memberikan perlindungan, serta berusaha untuk mengetahui keinginan dan kebutuhan masyarakat.

Menurut Undang-Undang Nomor 25 Tahun 2009 tentang Pelayanan Publik, yang dimaksud dengan pelayanan publik adalah kegiatan atau rangkaian kegiatan dalam rangka pemenuhan kebutuhan pelayanan sesuai dengan peraturan perundangundangan bagi setiap warga negara dan penduduk atas barang, jasa dan/atau pelayanan administratif yang disediakan oleh penyelenggara pelayanan publik.

Oleh karena itu, kualitas pelayanan publik dalam penelitian ini dimaksudkan sebagai proses pemberian layanan administratif oleh aparat penyelenggara untuk memenuhi kebutuhan dan harapan warga masyarakat, dilihat dari langkah-langkah atau cara-cara melalui dimensi-dimensi yaitu; 1) reliability pelayanan, 2) responsiveness pelayanan, 3) asuransi pelayanan, 4) empathy pelayanan, dan 5) tangibles pelayanan, 6) efektivitas pelayanan, dan 7) efisiensi pelayanan.

\section{Metode Penelitian}

Penelitian ini bersifat deskriptif kualitatif dengan tujuan untuk melakukan analisis dan menjelaskan mengenai kualitas pelayanan publik, serta dimensi-dimensi profesionalisme kerja yang menjadi faktor-faktor pendukung dan penghambatnya pada Kantor Dinas Kependudukan dan Pencatatan Sipil Kota Ambon. Penelitian ini dilaksanakan dengan struktur penelitian sebagai berikut; 
1. Jenis data yang dibutuhkan dalam penelitian ini, terdiri atas data yang bersifat primer dan data yang bersifat sekunder.

2. Teknik penentuan informan dalam penelitian ini menggunakan teknik purposive sampling.

3. Informan kunci (key Informan) dalam penelitian ini mencakup pihak - pihak yang dipandang dekat dan mengetahui secara langsung data dan informasi mengenai masalah. Berjumlah 11 orang, dimana kelompok internal berjumlah 5 orang dan kelompok eksternal berjumlah 6 orang.

4. Data primer berumber dari informan penelitian yang dijaring melalui wawancara mendalam (depth interview), observasidan dokumentasi. Sementara data sekunder, dari penelusuran dan pengamatan terhadap dokumen-dokumen tertulis pada lokasi penelitian dan studi kepustakaan (library research).

5. Teknis analisis data menggunakan teknik kualitatif deskriptif.

\section{Pembahasan Hasil Penelitian}

Data yang berhasil dikumpulkan dari penelitian lapangan mengenai kualitas pelayanan publik setelah diolah, dilakukan analisis sebagai pembahasan hasil sebagai berikut.

\section{Kualitas Pelayanan Publik}

Pelayanan menurut Kamus Besar Bahasa Indonesia (KBBI) adalah sebagai suatu usaha untuk membantu menyiapkan atau mengurus apa yang diperlukan orang lain. Kualitas pelayanan publik bidang administrasi kependudukan dan pencatatan sipil merupakan salah satu faktor penting yang harus diwujudkan oleh pimpinan dan aparat penyelengggarannya pada Dinas ini. Untuk melihat tinggi atau rendahnya tingkat kualitas pelayanan yang diberikan, digunakan tujuh dimensi yakni: Reabilty, Responsiveness, Assurance, Empathy, Tangibles, Efektivitas dan Efisiensi Pelayanan. Berdasarkan pemaparan hasil analisis data diatas yang dihimpun dari penelitian lapangan, diperoleh gambaran mengenai kualitas pelayanan publik secara administratif oleh aparat penyelenggara di Kantor Dinas Kependudukan dan Pencatatan Sipil.

\section{a. Dimensi Responsiveness (Ketanggapan)}

Responsiveness (ketanggapan) merupakan kemampuan aparatur dalam mengantisipasi dan menghadapi aspirasi baru, perkembangan baru, tuntutan baru, dan pengetahuan baru. Menurut (Sondang P. Siagian, 2014) bahwa tidak tanggap 
dapat berarti kekecewaan rakyat yang pada gilirannya mungkin berakibat pada timbulnya krisis kepercayaan kepada pemerintah.

Dalam upaya memenuhi kebutuhan dan harapan warga masyarakat, berada dalam kondisi baik terutama dari dimensi responsiveness(ketanggapan), dalam hal pegawai selalu menampilkan sikap tanggap dalam memberikan layanan bagi warga yang membutuhkan. Hasil penelitian menunjukan bahwa tampaknya dimensi responsiveness pelayanan publik bidang administratif pada kantor Dinas Kependudukan dan Pencatatan Sipil Kota Ambon berada pula dalam kondisi sangat baik dikarenakan adanya hasil wawancara yang menunjang antara Plt. Kepala Dinas sekaligus Sekretaris (Ibu M.H) selaku pimpinan dengan staf penyelenggara Kasubag Bidang Pelayanan Pendaftaran Penduduk (Ibu JL). Kemudian dengan hasil wawancara kelima informan warga masyarakat yang sependapat karena kinerja para pegawai sejauh ini telah dilihat mampu dan cepat tanggap sesuai tugas masingmasing dalam memberikan pelayanan di kantor.

\section{b. Dimensi Reliability (Keandalan)}

Kehandalan dalam berupa kemampuan perusahaan untuk memberikan pelayanan sesuai denganyang dijanjikan secara akurat dan terpercaya. Kinerja harus sesuai dengan harapan pelanggan yang berarti ketepatan waktu, pelayanan yang sama, untuk semua pelanggan tampa kesalahan, sikap yang simpatik, dan dengan akurasi yang tinggi'.

Pada dimensi reliability (keandalan), tampak dari pegawai selalu memperlihatkan sikap andal dalam memberikan layanan bagi warga yang membutuhkan, hasil penelitian menunjukan bahwa tampaknya dimensi reliability pelayanan publik bidang administratif pada kantor dinas kependudukan dan pencatatan sipil kota Ambon berada dalam kondisi baik dikarenakan terdapatnya kesesuaian hasil wawancara dengan Plt. Kepala Dinas sekaligus Sekretaris (Ibu M.H) selaku pimpinan dengan staf penyelenggara Kasubag perencanaan dan Keuangan (Bapak R.P), serta Kabid Umum dan Kepegawaian (Ibu L.M). Hal ini pun didukung dengan hasil wawancara keempat informan warga masyarakat yang sependapat karena puas dengan kecermatan pelayanan di kantor meskipun hanya satu informan yang tidak sependapat. 


\section{Dimensi Efisiensi (Cara - cara terbaik)}

Menurut Sondang P. Siagian, (2014);

"Efisiensi diartikan sebagai perbandingan yang terbaik antara input (masukan) dengan output (hasil antara keuntungan dengan sumber-sumber yang digunakan), seperti juga hasil optimal yang diperoleh dengan penggunaan sumber yang terbatas. Atau dapat dikatakan sebagai hubungan antara apa yang telah diselesaikan".

Dimensi efisiensi (cara-cara terbaik), hal ini dapat disimak dari pegawai selalu menampilkan cara yang murah, mudah, dengan jarak yang pendek, dan cara yang ringan. Oleh karena itu hasil wawancara dengan Plt. Kepala Dinas sekaligus Sekretaris (Ibu M.H) selaku pimpinan saling melengkapi dengan staf penyelenggara dalam hal ini Kepala Bidang Pelayanan Pencatatan Sipil (Ibu R.S), tentang dimensi efisiensi dalam pelayanan publik kepada warga masyarakat yang membutuhkan, kemudian disesuaikan dengan keempat informan warga masyarakat yang sependapat karena dirasakan sudah mampu menunjukkan pengunaan cara kerja dengan prosedur yang pendek, murah, ringan, dan mudah bagi warga masyarakat di kantor, meskipun hanya satu informan yang tidak sependapat. Sehingga dari data informan diatas menunjukan bahwa tampaknya dimensi efisiensi pelayanan publik bidang administratif pada kantor dinas kependudukan dan pencatatan sipil kota Ambon berada dalam kondisi baik.

\section{d. Dimensi Emphaty (Empati)}

Menurut Fandy Tjiptono dan Gregorius Chandra, (2005);

"Empati merupakan kemudahan dalam melakukan hubungan, komunikasi yang baik, perhatian pribadi, dan memahami kebutuhan para konsumen. Setiap anggota perusahaan hendaknya dapat mengelola waktu agar mudah dihubungi, baik melalui telepon ataupun bertemu langsung. Dering telepon usahakan maksimal tiga kali, lalu segera djawab. Ingat, waktu yang dimiliki pelanggan sangatterbatas sehingga tidak mungkin menunggu terlalu lama".

Bersumberdari data hasil wawancara dan observasi menunjukan bahwa tampaknya dimensi emphaty pelayanan publik bidang administratif pada kantor dinas kependudukan dan pencatatan sipil kota Ambon berada dalam kondisi cukup, karena hasil petikan wawancara dengan dengan Plt. Kepala Dinas sekaligus Sekretaris (Ibu M.H) selaku pimpinan dengan staf penyelenggara yaitu Kasubag Bidang Pelayanan dan Pencatatan Sipil (Ibu R.S), tentang dimensi empathy dalam pelayanan publik kepada warga masyarakat yang membutuhkan didukung oleh keempat informan warga masyakat lainnya dan hanya satu pendapat saja yang bertolak belakang dari informan Ibu Y.A. dapat dilihat sikap pegawai yang terkadang 
berusaha untuk mengetahui masalah dan keluhan yang dihadapi warga yang datang berurusan.

\section{e. Dimensi Assurance (Jaminan)}

Definisi jaminan dalam Lupiyoadi, (2001) yaitu;

"Pengetahuan, kesopan santunan, dan kemampuan para pegawai perusahaan untuk menumbuhkan rasa percaya para pelanggan kepada perusahaan. Terdiri dari beberapa komponen antara lain komunikasi (communication), kredibilitas (credibility), keamanan (security), kompetensi (competence) dan sopan santun (courtesy)".

Berdasarkan hasil-hasil wawancara diatas menunjukan bahwa tampaknya dimensi assurance pelayanan publik bidang administratif pada Kantor dinas kependudukan dan pencatatan sipil kota Ambon berada dalam kondisi cukup. Dalam hal ini, hasil wawancara dengan Plt. Kepala Dinas sekaligus Sekretaris (Ibu M.H) yang menyatakan telah memaksimalkan kualitas para pegawainya mulai dari pembinaan, pelatihan, sosialisasi bahkan adanya evaluasi, namun tentunya attitude itu kembali ke masing-masing pribadi para pelayan publik. Data pun dikobinasikan melalui wawancara dengan staf penyelenggara dalam hal ini kasubag Bidang Piak dan Pemanfaatan Data (Ibu H.T) sebagai informan pegawai yang melakukan kegiatan di kantor bahwa beliau sendiri telah maksimal dalam memberikan pelayanan. Informasi dari kelima informan warga masyarakat, hanya dua Informan (Ibu M.M) dan (Bapak M.R) yang setuju serta puas dengan pelayanan yang mereka dapatkan, akan tetapi tiga informan lainnya (BapakY.I), (Ibu Y.A) dan (Ibu S.L) yang berpendapat bahwasanya untuk hal kesopanan tersebut dirasakan kurang terlalu nampak karna juga tergantung pada sifat dan karakter masing-masing pribadi dari para pegawai yang berbeda satu dengan yang lain. Dimensi assurance (jaminan) berada dalam kondisi cukup. Disisi lain terhadap Dimensi assurance/jaminan dalam pemberian pelayanan, pegawai berusaha untuk memberikan jaminan atas janji yang harus dipenuhi sesuai standar yang tersedia.

\section{f. Dimensi Efektivitas}

Efektivitas adalah suatu tingkat keberhasilan yang dihasilkan oleh seseorang atau organisasi dengan cara tertentu sesuai dengan tujuan yang hendak dicapai. Dengan kata lain, semakin banyak rencana yang berhasil dicapai maka suatu kegiatan dianggap semakin efektif. Pengertian efektivitas menurut Sondang P. Siagian, (2014) yakni; 
"Suatu pemanfaatan sarana prasarana, sumber daya dalam jumlah tertentu yang sebelumnya telah ditetapkan untuk menghasilkan sejumlah barang atau jasa kegiatan yang akan djalankan oleh seseorang atau suatu perusahaan."

Mengenai Dimensi efektivitas pegawai dalam pemberian pelayanan berdasarkan dengan hasithasil wawancara menunjukan bahwa tampaknya dimensi efektivitas pelayanan publik bidang administratif pada kantor dinas kependudukan dan pencatatan sipil kota Ambon berada dalam kondisi cukup. Dapat kita lihat pada dengan Plt. Kepala Dinas sekaligus Sekretaris (Ibu M.H) dengan Kepala Bidang Pelayanan Pendaftaran Penduduk (Ibu J.L) yang menilai bahwa apa yang dilakukan oleh pegawai telah maksimal dalam meningkatkan efektivitas pelayanan agar lebih baik dari yang dahulu, namun kembali lagi kepada output penilaian oleh masyarakat, data ini pun mendukung adanya tanggapan positif dari tiga informan warga masyarakat diantaranya (Ibu S.L, Ibu Y.A dan Ibu M.M), yang setuju bahwa pelayanan yang diterima sudah efektif dan tak bertele-tele bahkan jauh lebih baik daripada tahun-tahun sebelumnya. Hanya dua informan warga masyarakat yang pendapatnya terdengar berbeda yaitu (Bapak Y.I dan Bapak M.R) sebab mereka sendiri mengaku tidak tahu dan kurang memperhatikan perihal salah satunya tentang ketepatan waktu masuk kerja pegawai kantor. Melalui observasi sendiri tampak bahwa ketepatan waktu yang telah ditetapkan masih tidak selalu dapat dipenuhi, dalam arti waktu yang ditetapkan warga memperoleh hak layanan menjadi molor waktunya antara 1 - 3 hari, karena disebabkan kelengkapan persyaratan tidak dipenuhi warga, namun juga akibat kerusakan peralatan yang dipicu dari tinggi volume kerja, bahkan listrik tiba padam. Oleh karena itu, Dimensi Efektivitas berada dalam kondisi cukup.

\section{g. Dimensi Tangibles (Ketampakan)}

TangiIbles, yaitu bukti fisik dari jasa bisa berupa fasilitas fisik, peralatan yang dipergunakan, reorientasi fisik dari jasa. Definisi tangible menurut Wang \& Wang dalam Felix, (2017) adalah peralatan yang baru, fasilitas yang menarik, penampilan professional, dan materi yang berkaitan dengan pelayanan.

Dimensi tangibles (ketampakan) pada kantor Dinas Kependudukan dan Pencatatan Sipil Kota Ambon berada dalam kondisi masih kurang. Hal ini dapat dilihat melalui data observasi yang diamati dari ruang kantor secara umum sudah tidak representatif untuk menghandel volume kerja dalam proses pemberian layanan bagi warga masyarakat yang berurusan dengan jumlah banyak sehingga kantor menjadi 
penuh dan menyesakan, kapasitas Air Condition (AC) yang sangat kurang karena hanya tersedia satu buah di ruang tunggu.

Hasil data yang ditemukan melalui observasi kemudian digabungkan hasil wawancara informan telah menunjukan bahwa tampaknya dimensi tangibles pelayanan publik bidang administratif pada Kantor dinas kependudukan dan pencatatan sipil kota Ambon berada dalam kondisi kurang baik. Berikut hasil wawancara dengan Plt. Kepala Dinas sekaligus Sekretaris (Ibu M.H) yang memberikan tanggapan selalu mengupayakan evaluasi agar pegawai selalu terlihat prima dan maksimal memberikan pelayanan mulai dari attitude dan terkait ketampakkan kerapian dalam berseragam PNS, hanya saja adanya faktor kekurangan yang masih dirasakan salah satunya adalah keterbatasan ruangan dan fasilitas fisik. Senada dengan hasil wawancara yang dilakukan dengan staf penyelenggara dalam hal ini Kasubag Bidang Perencanaan (Bapak R.P) bahwa adanya standar-standar yang belum bisa dipenuhi, aturan-aturan untuk suatu ruangan yang layak sebab ruangan juga salah satu faktor mempengaruhi kinerja pegawai akan tetapi kita harus bisa menerima keadaan. Hal ini pun ditunjukkan dengan hasil wawancara dan obsevasipada kelima informan warga masyarakat yang lantas semua diantaranya, mengemukakan pendapat yang sama bahwa fasilitas berupa sarana dan prasarana masih amat sangat kurang, kecilnya ruangan menunggu. Apalagi, persediaan kursi yang terbatas, AC tak lagi terasa dingin dan kebersihan toilet yang hanya satu sebab lainnya terkunci serta tidak higienis.

\section{Profesionalisme Kerja Pegawai}

Profesionalisme kerja pegawai suatu organisasi, diukur melalui keahlian yang dimiliki seseorang yang sesuai dengan kebutuhan tugas yang dibebankan oleh organisasi kepada seseorang. Sehingga, tujuan organisasi dapat tercapai melalui peningkatan kualitas pelayanan kepada para pengguna jasa atau masyarakat yang ada ketika melakukan pengurusan terhadap masalah yang dialami. Guna mengetahui hal ini dapat ditampilkan hasil penelitian secara berurutan. Optimalnya kualitas pelayanan publik tersebut, memperoleh dukungan dari faktor profesionalisme kerja pegawai, terutama aspek;

\section{a. Faktor Tingkat Keterampilan Kerja}

Terbentuknya aparatur profesional memerlukan keahlian dan keterampilan kerja khusus yang dibentuk melalui pendidikan dan pelatihan sebagai instrument 
pemutakhiran. Jadi dengan keahlian dan keterampilan khusus yang dimiliki oleh aparatur memungkinkan terpenuhinya kecocokan antara kemampuan aparatur dengan kebutuhan tugas merupakan syarat terbentuknya aparatur yang professional.

Faktor tingkat keterampilan kerja yang berada dalam kondisi sangat baik. Dikarenakan pada tingkat keterampilan kerja tercapainya kesesuaian hasil wawancara antara Ptt. Kepala Dinas sekaligus Sekretaris (Ibu M.H) dengan Kepala Sub Bagian Umum dan Kepegawaian (Ibu L.M), tentang tingkat keterampilan kerja bahwasanya pentingnya diadakan bimtek dan adanya keahlian khusus yang mesti dimiliki oleh aparatur sipil Negara demi menunjang kesuksesan dalam pelayanan publik kepada warga masyarakat yang membutuhkan. Kemudian ditunjang dengan hasil observasi dan wawancara dari kelima informan yang semuanya setuju akan faktor keterampilan kerja pegawai telah sesuai dengan harapan, namun hanya perlu ditingkatkan saja untuk tidak telat dalam pemberian tanda tangan.

\section{b. Faktor Tingkat Kreativitas Kerja}

Menurut Sondang P. Siagian, (2014);

"Bahwa Kreatifitas (creativity) yaitu kemampuan aparatur untuk menghadapi hambatan dalam memberikan pelayanan kepada public dengan melakukan inovasi. Hal ini perlu diambil untuk mengakhiri penilaian miring masyarakat kepada birokrasi publik yang dianggap kaku dalam bekerja".

Terkait tingkat kreativitas kerja yang ditunjukan oleh pegawai yang juga berada dalam kondisi yang sangat baik sebab kesesuaian hasil wawancara antara PIt. Kepala Dinas sekaligus Sekretaris (Ibu M.H) dengan Kepala Bidang Piak dan Pemanfaatan Data (Ibu H.T), tentang dimensi tingkat kreatifitas dalam pelayanan publik kepada warga masyarakat yang membutuhkan bahwa pentingnya kreativitas dengan kesadaran dan tentu hal tersebut setiap pegawai ditempatkan karena dengan kreativitas yang memang dimiliki masing-masing. Hal ini juga dibenarkan oleh hasil observasi lapangan dan hasil wawancara dengan kelima informan warga masyarakat bahwasanya memang pegawai pada kantor Dinas Kependudukan dan Pencatatan Sipil Kota Ambon dinilai telah memenuhi kriteria memiliki kreativitas dan bekerja sesuai ketentuan yang ditetapkan.

\section{c. Faktor Tingkat Pengalaman Kerja}

Menurut Wariati, (2015);

"Pengalaman kerja adalah suatu pengetahuan, keterampilan, dan kemampuan yang dimiliki pegawai untuk mengemban tanggung jawab dari pekerjaan sebelumnya". 
Faktor ini mendapatkan yang mendapatkan predikat baik pada Kantor Dinas Kependudukan dan Pencatatan Sipil Kota Ambon. Dikarenakan pada tingkat pengalaman kerja ditemukan pula kesesuaian hasil wawancara antara Plt. Kepala Dinas sekaligus Sekretaris (Ibu M.H) dengan staf penyelenggara dalam hal ini Kepala Bidang Piak dan Pemanfaatan Data (Ibu H.T), tentang faktor tingkat pengalaman dalam pelayanan publik kepada warga masyarakat yang membutuhkan bahwa memang prosedur dan aturan-aturan dasar pelayanan itu semua sudah diketahui tinggal bagaimana untuk untuk selalu saling mengingatkan satu sama lain karena para pegawai pada kantor pun telah rata- rata bekerja diatas lima tahun. Hal ini pun diperkuat dengan hasil observasi dan hasil wawancara terhadap keempat dari lima informan warga masyarakat yang menyatakan tingkat pengalaman dari pegawai di kantor dalam pemberian pelayanan sudah baik sebab mereka sering memberikan pelayanan secara kontinu terhadap masyarakat, meski hanya satu saja informan warga masyarakat yang hasil wawancaranya berbeda.

\section{d. Faktor Tingkat Disiplin Kerja}

Menurut Veithzal Rivai, (2004);

"Disiplin kerja adalah suatu alat yang dipergunakan para manajer untuk berkomunikasi dengan karyawan agar mereka bersedia untuk mengubah suatu perilaku serta sebagai suatu upaya untuk meningkatkan kesadaran dan kesediaan seorang dalam memenuhi segala peraturan perusahaan".

Pada tingkat disiplin kerja, melalui hasil wawancara antara Plt. Kepala Dinas sekaligus Sekretaris (Ibu M.H) dengan staf penyelenggara dalam hal ini Kepala Sub Bagian Perencanaan dan Keuangan (Bapak R.P), mengungkapkan Perihal masuk tepat waktu, disini sudah ada aturannya dengan adanya peraturan pemerintah nomor 53 tahun 2010 tentang disiplin PNS dimana masuk kantor jam 8 pagi dan pulang jam 5 sore, istirahat yaitu hanya sampai jam 1 siang selain hari jumat yang sampai jam 2 siang kalau tak disiplin maka TPP dipotong sebagai konsekuensi. Hasil pengamatan lapangan melalui observasi pun mendukung bahwa tingkat kedisiplinan pegawai sudah sesuai dengan harapan pelayanan publik dan hal ini juga mendapat respon yang baik dengan hasil wawancara informan warga masyarakat. Keempat informan dari kelimanya setuju kedisplinan pegawai sudah baik sebab pegawai selalu tepat waktu dan jam kantor. 


\section{e. Faktor Tingkat Inovasi Kerja}

Inovasi bermaksud agar aparatur menciptakan suatu model kerja baru tetapi juga bertujuan untuk mencapai suatu kepuasan kerja bagi individu maupun organisasi dan kepuasan pelayanan bagi masyarakat.

Pada tingkat inovasi kerja, dimana melalui adanya kesesuaian hasil wawancara antara Ptt. Kepala Dinas sekaligus Sekretaris (Ibu M.H) dengan staf penyelenggara dalam hal ini Kepala Sub Bagian Perencanaan dan Keuangan (Bapak R.P), mengenai inovasi tentu masing inovasi masing-masing bidang amatlah berbeda namun selalu ada inovasi terutama dalam pemberian pelayanan maupun program program kerja mengedukasikan demi warga masyarakat. Hasil observasi yang dilakukan menunjukan adanya kotak saran dan pendapat yang terdapat pada ruang pelayanan masyarakat di kantor. Tentunya hal ini menunjukan bahwa kantor Dinas Kependudukan dan Pencatatan Sipil Kota Ambon menghargai masukkan masyarakat demi agar pelayanan kedepan semakin inovatif. Bersama ini, didukung dengan adanya hasil wawancara dari kelima informan warga masyarakat, dimana keempat diantara menyetujui bahwa pegawai di kantor sudah menunjukan kinerja yang berinovasi dalam memberikan pelayanan administratif.

\section{f. Faktor Tingkat Pengetahuan Kerja}

Menurut Reber, (2010) bahwa komponen-komponen mental yang dihasilkan dari semua proses apapun, entah lahir dari bawaan atau dicapai lewat pengalaman, sehingga hal ini dapat diterapkan demi meningkatkan profesionalitas kerja.

Faktor penghambat terhadap kualitas pelayanan publik dalam penelitian ini adalah Tingkat Pengetahuan Kerja, sebab meski terdapat kesesuaian hasil wawancara antara Plt. Kepala Dinas sekaligus Sekretaris (Ibu M.H) dengan staf penyelenggara dalam hal ini Kepala Bidang Piak dan Pemanfaatan Data (Ibu H.T), tentang terkait tingkat pengetahuan pegawai dalam pelayanan publik kepada warga masyarakat yang membutuhkan mengemukakan bahwa mereka selalu berupaya meningkatkan pelayanan kepada masyarakat melalui pengalaman dan pengetahuan yang dimiliki, namun semua kembali kepada penilaian akhir masyarakat akan hasil kerja maupun kemampuan pegawai, berdasarkan hasil observasi yang dilakukan dengan hasil wawancara kepada infoman warga masyarakat yang dilakukan, ketiga informan dari lima menyatakan pegawai sudah 
mampu menunjukan tingkat pengetahuan yang tinggi terhadap mekanisme dan prosedur kerja, meski hanya dua informan yang tak sependapat.

\section{g. Faktor Tingkat Kesanggupan Kerja}

Kesanggupan kerja atau kecakapan kerja merupakan seseorang yang memiliki kecakapan atau kesanggupan untuk menjalankan sesuatu yang diwujudkan melalui tindakannya untuk meningkatkan produktivitas kerjanya. Kesanggupan berupa kemampuan (ability) merupakan suatu kapasitas individu untuk mengerjakan berbagai tugas dalam suatu pekerjaan.

Terkait tingkat kesanggupan kerjapun, dari hasil wawancara antara Ptt. Kepala Dinas sekaligus Sekretaris (Ibu M.H) dengan Kepala Kepala Bidang Pelayanan Pencatatan Sipil (Ibu R.S) diketahui bahwa kesanggupan tentunya berkaitan dengan aturan-aturan maupun prosedur-prosedur yang melalui pembinaan dan pendampingan karena meskipun pegawai telah paham peraturan namun apabila tak ada pendampingan atau pelatihan maka pegawai akan sulit memotivasi diri dalam memacu peningkatan dedikasi/loyalitas dalam kesanggupan kerja. Sesuai dengan hasil observasi lapangan dan hasil wawancara dari kelima informan warga masyarakat maka diketahui bahwa empat diantaranya setuju akan tingkat kesanggupan pegawai sudah sesuai melalui pelayanan yang diterima, namun satu informan diantara menyatakan kontra sebab Tingkat kesanggupan pegawai dalam bekerja masih dirasakan terbatas sebab terlihat dari batas nomor antrian yang ada. Sehingga kedua faktor dalam professionalisme ini masih dalam posisi kurang pada Dinas Kependudukan dan Pencatatan Sipil Kota Ambon.

Oleh karena itu dapat dikemukakan bahwa tingkat kualitas pelayanan publik oleh aparat penyelenggara bidang administrasi kependudukan dan pencatatan sipil pada Dinas Kependudukan dan Pencatatan Sipil Kota Ambon, merupakan kontribusi dari faktor profesionalisme kerja para pegawainya, terutama tingkat keterampilan kerja, tingkat kreativitas, tingkat pengalaman, tingkat disiplin, dan tingkat inovasi. Atau dengan kata lain dapat diungkapkan bahwa profesionalisme kerja pegawai atau aparat pada suatu organisasi publik atau pemerintahan dapat mempengaruhi kondisi kualitas pelayanan publik yang diberikan sesuai dengan visi dan misi yang telah ditetapkan sebelumnya. Dengan demikian optimal atau tingkat kualitas pelayanan publik pada Dinas Kependudukan dan Pencacatan Sipil Kota Ambon, sangat 
ditentukan oleh sejumah aspek pendukung dari faktor profesionalisme kerja pegawai sebagaimana yang dikemukakan diatas.

\section{Penutup}

\section{Kesimpulan}

Kualitas pelayanan publik secara administratif oleh aparatur penyelenggara di Kantor Dinas Kependudukan dan Pencatatan Sipil berada dalam kondisi baik terutama, dari dimensi responsiveness (ketanggapan), dimensi reliability (keandalan) dan dimensi efisiensi (cara-cara terbaik). Sementara dimensi yang berada dalam kondisi cukup adalah dimensi emphaty (empati), dimensi assurance (jaminan) dan dimensi efektivitas. Disisi lain dimensi yang berada dalam kondisi masih kurang yakni, dimensi tangibles (ketampakan) berada dalam kondisi masih kurang.

Optimalnya kualitas pelayanan publik tersebut, memperoleh dukungan dari faktor profesionalisme kerja pegawai, terutama aspek: tingkat keterampilan kerja, tingkat kreativitas, tingkat pengalaman, tingkat disiplin, dan tingkat inovasi. Sementara faktor penghambat dari professionalime kerja terhadap kualitas pelayanan publik dalam penelitian ini adalah tingkat pengetahuan dan tingkat kesanggupan yang berada dalam posisi kurang.

Secara kumulatif dapat disimpulkan bahwa tingkat kualitas pelayanan publik bidang administrasi kependudukan oleh aparat penyelenggara di Kantor Dinas Kependudukan dan Pencatatan Sipil Kota Ambon berada dalam kondisi cukup hal ini dapat dipengaruhi tingkat profesionalisme kerja para aparatnya.

\section{Daftar Pustaka}

Fandy Tjiptono dan Gregorius Chandra. (2005). Manajemen Kualitas Jasa. Yogyakarta: Andi.

Felix, R. (2017). Service Quality and Customer Satisfaction in Selected Banks in Rwanda. Journal of Business \& Financial Affairs, 06(01), 1-11. https://doi.org/10.4172/21670234.1000246

Lupiyoadi, R. (2001). Manajemen Pemasaran Jasa. Jakarta: Salemba Empat. Mukarom, Zainal \& Laksana, M. W. (2016). Membangun Kinerja Pelayanan Publik Menuju Clean Government and Good Governance. Bandung: Pustaka Setia.

Peraturan Pemerintah RI Nomor 37 Tahun 2007. (2007). Pelaksanaan Undang-Undang Nomor 23 Tahun 2006 Tentang Administrasi Kependudukan. Retrieved from 
https://peraturan.bpk.go.id/Home/Details/4759/pp-no-37-tahun-2007

Peraturan Walikota Ambon Nomor 38 Tahun 2016. (2016). Organisasi dan Tata Kerja Dinas Kota Ambon. Retrieved from

https://peraturan.bpk.go.id/Home/Details/121339/perwali-kota-ambon-no-38-

tahun-2017

Sedarmayanti. (2012). Good Governance: Kepemerintahan Yang Baik Dalam Rangka Otonomi Daerah Upaya Membangun Efektif dan Efisien Melalui Restrukturisasi dan Pemberdayaan. Bandung: Mandar Maju.

Sondang P. Siagian. (2014). Administrasi Pembangunan. Jakarta: Bumi Aksara.

Supriyono. (2001). Sistem Pengendalian Manajemen. Jakarta: Erlangga.

Undang-Undang Nomor 23 Tahun 2006. (2006). Administrasi Kependudukan.

Undang-Undang Nomor 24 Tahun 2013. (2013). Perubahan Atas Undang-Undang Nomor 23 Tahun 2006.

Undang-Undang Nomor 25 Tahun 2009. (2009). Pelayanan Publik.

Veithzal Rivai. (2004). Manajemen Sumber Daya Manusia Untuk Perusahaan. Jakarta: PT Raja Grafindo Persada.

Wariati. (2015). Pengelolaan Keuangan Dan Aset Kabupaten Barito Timur . Jurnal Wawasan Manajemen, 3(3), 217-228. Retrieved from https://jwm.ulm.ac.id/id/index.php/jwm/article/view/3 